\title{
TELAAH EKONOMI POLITIK PERAN INVESTOR \\ DALAM PEMBANGUNAN TRANSPORTASI PUBLIK DI DAERAH WISATA KUTA BALI
}

\author{
Emma Ratna Sari Moedy \\ Fakultas Ilmu Sosial dan Ilmu Politik Universitas Mahendradatta Denpasar \\ emmamoedy@gmail.com
}

\begin{abstract}
Abstrak - Masalah kemacetan sudah mengakar di daerah wisata. Penyebabnya sangat kompleks. Peranan investor dalam tata kelola pemerintahan di Kuta, Bali, Indonesia, diangkat dalam bentuk tulisan tentang wacana publik utamanya soal implementasi kebijakan publik. Diskusi dan penelitian sosial ini dibuat untuk para pelaku bisnis di Kuta. Dibutuhkan penanganan yang komprehensif jadi tidak hanya diatasi dari satu sisi saja. Sinergi pemerintah, swasta dan investor sangat dibutuhkan agar dapat memberikan jaminan terhadap kelancaran, kepastian, kenyamanan, keterjangkauan dan keselamatan yang lebih baik. Hal ini hanya akan dapat dicapai bila konsep perencanaannya benar, pelaku-pelaku (stakeholders) bersatu padu, kebijakan pemerintah mendukung, ketaatan masyarakat tinggi dan penerapan law enforcement yang tegas. Kontinuitas dan keterpaduan antarmoda transportasi juga merupakan bagian yang menjadi syarat untuk menjadikan tingkat kualitas yang lebih baik. Dengan demikian akan dapat dicapai efektivitas dan efisiensi yang pada akhirnya akan dapat mendukung upaya mengatasi kemacetan dan pada akhirnya menyejahterakan masyarakat. Wajah lalu lintas dan transportasi publik merupakan cermin dari wajah Bali sebagai destinasi wisata dunia.
\end{abstract}

Kata kunci: investasi, tujuan wisata internasional, transportasi publik, implementasi kebijakan publik

\begin{abstract}
Traffic jam is sosial problem in Kuta, Bali, Indonesia. The congestion problem has taken root in tourism destination. The causes are complex. The role of investors in governance in Kuta, Bali, Indonesia, was appointed in the form of writing about public discourse primarily about the implementation of public policy. This discussion and social research was made for business people in Kuta. Comprehensive handling is needed so it is not only handled from one side only. The synergy of the government, private sector and investors is urgently needed in order to be able to provide guarantees for smoothness, certainty, comfort, affordability and better safety. This can only be achieved if the concept of planning is correct, actors are united, government policies support, high public observance and strict enforcement of law enforcement. Continuity and integration between transportation modes is also a prerequisite for better quality levels. Thus, effectiveness and efficiency will be achieved which in turn will support efforts to overcome congestion and ultimately improve the welfare of the community. The face of traffic and public transportation is a reflection of Bali's face as a world tourist destination.
\end{abstract}

Keywords: investor, traffel destinations, public transformations, implementation of public policy 


\section{Latar Belakang}

Kemacetan di daerah wisata bagaikan dua sisi uang. Ramainya kunjungan wisata mau tidak mau membawa dampak makin meningkatnya kemacetan di sekitar daerah wisata tersebut. Daerah wisata sejatinya menawarkan kenyamanan, keamanan, suasana rekreatif yang kondusif sehingga yang datang berwisata dapat rileks, santai dan menikmati perjalanannya. Namun seperti yang sudah disebutkan di awal ketika suatu daerah wisata menjadi favorit maka ruas-ruas jalan di sekitarnya umumnya mengalami kemacetan. Padahal kemacetan merupakan simbol dari ketidaknyamanan, ketidakamanan, stress dan hal negatif lainnya. Kemacetan merupakan sesuatu yang mau tidak mau mengikuti pesatnya pertumbuhan wisata. Namun kemudian situasi macetnya lalu lintas menjadi boomerang bagi daerah wisata tersebut. Diperlukan penanganan yang komprehensif agar masalah kemacetan dapat terurai dan diminimalisir sebelum pada akhirnya daerah wisata tersebut ditinggalkan akibat ketidaknyamanan dalam mengakses daerah tersebut.

Bali sebagai destinasi wisata favorit Indonesia dan dunia memiliki banyak tempat-tempat menarik untuk dikunjungi. Kuta merupakan salah satu destinasi wisata paling favorit bagi para pelancong domestik dan mancanegara. Tingginya minat wisatawan untuk mengunjungi Bali khususnya Kuta, membuat akses jalan menuju dan keluar dari Kuta sering kali macet. Kemacetan akan semakin panjang pada saat libur panjang, longweekend, atau tanggal merah. Dinas Infokom dan Perhubungan Provinsi Bali, menyebutkan bahwa jumlah kendaraan bermotor di Pulau Dewata mencapai 5,1 juta unit. Dari jumlah tersebut, yang terdeteksi bernomor polisi Bali hanya sebanyak 3 juta unit. Dari 2,1 juta kendaraan bermotor bernomor polisi non Bali tersebut diantaranya adalah kendaraan para wisatawan yang da- tang mengunjungi Bali (http: //suaradewata.com/read/ 2016/04/01/201604010011/ Di-Bali-Kendaraan-Bermotor-Capai-5Juta-Unit.html). Kuta sebagai icon Bali pasti menjadi destinasi wisata yang wajib dikunjungi wisatawan.

Kondisi badan jalan yang tidak terlalu lebar tidak sebanding dengan jumlah kendaraan yang keluar masuk Kuta. Kendaraan didominasi oleh kendaraan pribadi (mobil dan sepeda motor), angkutan umum (sewa atau transportasi publik) seperti bis wisata, travel, shuttle bus dan lain-lain meramaikan akses di sekitar Kuta. Kemacetan diperparah lagi dengan minimnya lokasi parkir sehingga sering kita jumpai banyak kendaraan parkir di badan jalan. Jalan yang sudah sempit menjadi semakin sempit termakan ruang untuk parkir.

Untuk mengantisipasi masalah kemacetan yang semakin parah sebagai efek dari semakin meningkatnya angka kunjungan wisatawan ke Kuta, maka diperlukan upaya untuk menata kembali kawasan Kuta baik dari segi tata ruang, transportasi (utamanya transportasi publik) dan kepariwisataannya. Pengelolaan tata ruang utamanya untuk pembangunan jalan baru akan banyak mengalami kendala. Budaya dan tingginya biaya untuk pembebasan lahan merupakan tantangan apalagi bagi daerah Kuta yang memiliki kepadatan bangunan fisik. Hal yang memungkinkan untuk dilakukan adalah pembenahan tranportasi publik. Saat ini telah ada transportasi publik yang beroperasi di sekitaran Kuta namun belum dapat beroperasi maksimal karena minimnya penumpang. Keengganan masyarakat beralih dari transportasi pribadi ke transportasi publik disebabkan oleh faktor kenyamanan, keamanan, konektifitas yang masih rendah, ketidaktepatan jadwal keberangkatan, serta mahalnya biaya tranportasi publik. Faktor kualitas dan kuantitas tranporta- 
si publik menjadi perlu untuk dikaji jika ingin mengatasi semakin tingginya kepadatan lalu-lintas di daerah wisata Kuta. Daerah Kuta yang bukan hanya destinasi wisata domestik namun juga berkelas internasional harusnya memiliki transportasi publik berskala internasional pula.

\section{Obyek Wisata Kuta}

Lokasi obyek wisata Kuta berada sekitar $2 \mathrm{~km}$ sebelah utara Bandara Ngurah Rai, Tuban atau sekitar $10 \mathrm{~km}$ dari Kota Denpasar. Dahulu Kuta dan Pantai Kuta merupakan sebuah perkampungan nelayan juga dipergunakan sebagai pelabuhan niaga dan maritim untuk kerajaan-kerajaan di Bali. Sekarang Kuta menjadi kota kecil internasional lengkap dengan sarana dan prasarana penunjang pariwisata. Pantainya yang berpasir putih sepanjang kurang lebih $4 \mathrm{~km}$ tersebut sangat digemari oleh wisatawan untuk berjemur, menikmati sunset ataupun berselancar dan renang. Tersedia tenaga penyelamat pantai, publik shower, areal parkir, shuttle servis serta berbagai fasilitas kepariwisataan. Biaya masuk obyek wisata pun gratis.

\section{Kemacetan di wilayah Kuta}

Sudah menjadi rahasia umum saat ini kondisi lalu lintas di Kuta sudah sangat memprihatinkan, sudah dirasakan kemacetan yang semakin parah. Jalan Raya Kuta, Jalan Pantai Kuta, Jalan Sunset Road, Jalan Kartika Plaza, dan Jalan Raya Legian merupakan jalur terparah kemacetannya. Kemacetan juga terjadi di Jalan Teuku Umar, Jalan Imam Bonjol, dan juga kawasan Kerobokan. Kemacetan tersebut dikarenakan wisatawan terfokus pada Pantai Kuta dan wilayah Kuta. Tidak lengkap kalau ke Bali tidak berwisata ke Kuta, demikian jargon kebanyakan wisatawan sehingga objek wisata Kuta menjadi semakin padat. Jumlah kendaraan meningkat sementara jalan tidak ada perubahan. Upaya pelebaran jalan tidak memungkinkan sebab kawasan Kuta sudah padat dipenuhi bangunan. Diperlukan biaya yang besar dan waktu yang panjang untuk pembebasan lahan jika solusi pelebaran jalan diterapkan.

Padatnya bangunan untuk usaha wisata di daerah Kuta tidak dibarengi dengan adanya fasilitas lahan parkir yang memadai. Para pemilik usaha restoran, kios, mall, hotel, penginapan, tidak menyisakan ruang yang cukup untuk parkir. Ini memicu para pemilik kendaraan untuk tidak tertib. Parkir sembarangan di badan jalan menjadi hal yang lumrah kita saksikan. Jalanan yang sempit menjadi bertambah sempit akibat parkir sembarangan ini. Saat ini telah ada central parkir Kuta sebagai lokasi bagi para wisatawan untuk memarkirkan kendaraannya baik itu bus-bus wisata maupun kendaraan pribadi. Namun central parkir Kuta kian sepi. Bus pariwisata memilih parkir di lokasi yang lebih dekat pantai sesuai dengan permintaan penyewa bus. Kendala jarak $(1,7 \mathrm{~km}$ atau kurang lebih 10 menit berkendara dari central parkir ke pantai Kuta, waktu tempuh tersebut jika kondisi jalan tidak macet), jarangnya angkutan umum (komotra) yang beroperasi untuk rute central parkir-Kuta dan minimnya fasilitas penunjang membuat central parkir ini kurang diminati. Tujuan dari pengadaan central parkir Kuta menjadi tidak maksimal karena bus-bus pariwisata berbadan besarpun tetap mendekat ke pantai Kuta. Alih fungsi central parkir Kuta sebagai areal event dan konser membuat lokasi ini sering ditutup. Pada situasi atau hari-hari tertentu kemacetan juga disebabkan adanya upacara-upacara yang diadakan di pantai Kuta. Walaupun upacara-upacara ini juga menarik wisatawan namun tak dapat dipungkiri jika adanya upacara semacam ini memperlambat laju kendaraan, walaupun sifatnya insidentil. Padatnya pemban- 
gunan di seputar obyek wisata Kuta juga menyebabkan kurang maksimalnya sistem drainase. Sering kali jalanan Kuta banjir bahkan bisa terjadi di saat hujan tidak turun. Faktor ini pun menjadi salah satu penyebab banjir di seputaran Kuta. Genangan air membuat kendaran sulit melaju, macetpun lagi-lagi tidak terhindarkan. Mengutip pernyataan Tofan Priyanto, pertumbuhan moda transportasi publik yang memadai dan sesuai dengan budaya dan kondisi jalanan di areal Kuta pun mengalami perkembangan yang stagnan.

\section{Tinjauan Politik Kemacetan dan Trans- portasi Publik di Kuta}

Permasalahan kemacetan yang mengiringi pesatnya pertumbuhan lokasi wisata pantai Kuta, dapat dianalisis dari aspek:

1. Undang-undang Nomor 10 Tahun 2009 tentang Kepariwisataan (Lembaran Negara Republik Indonesia Tahun 2009 Nomor 11; Tambahan Lembaran Negara Republik Indonesia Nomor 4966; Undang-undang ini dibuat salah satunya dengan menimbang bahwa kepariwisataan merupakan bagian integral dari pembangunan nasional yang dilakukan secara sistematis, terencana, terpadu, berkelanjutan, dan bertanggung jawab dengan tetap memberikan perlindungan terhadap nilai-nilai agama, budaya yang hidup dalam masyarakat, kelestarian dan mutu lingkungan hidup, serta kepentingan nasional;

2. Peraturan Daerah Provinsi Daerah Tingkat I Bali Nomor 16 Tahun 2009 tentang Rencana Tata Ruang Wilayah Provinsi Bali Tahun 2009-2029. (Lembaran Daerah Provinsi Bali Tahun 2009 Nomor 16, Tambahan Lembaran Daerah Provinsi Bali Nomor 15). Dalam perda ini disebutkan tentang Kawasan Pariwisata didefinisikan sebagai kawasan strategis pariwisata yang berada dalam geografis satu atau lebih wilayah administrasi desa/kelurahan yang di dalamnya terdapat potensi daya tarik wisata,aksesibilitas yang tinggi, ketersediaan fasilitas umum dan fasilitas pariwisata serta aktivitas sosial budaya masyarakat yang saling mendukung dalam perwujudan kepariwisataan. Kawasan Daya Tarik Wisata Khusus, yang selanjutnya disebut KDTWK, adalah kawasan strategis pariwisata yang berada dalam geografis satu atau lebih wilayah administrasi desa/kelurahan yang di dalamnya terdapat potensi daya tarik wisata, aksesibilitas yang tinggi, ketersediaan fasilitas umum dan fasilitas pariwisata secara terbatas serta aktivitas sosial budaya masyarakat yang saling mendukung dalam perwujudan kepariwisataan, namun pengembangannya sangat dibatasi untuk lebih diarahkan kepada upaya pelestarian budaya dan lingkungan hidup.

Pasal 22 dari Perda ini mengatur tentang Rencana Pengembangan Sistem Jaringan Transportasi Darat. Selanjutnya pada ada pasal 25 diatur tentang:

(1) Peningkatan kuantitas dan kualitas pelayanan angkutan umum

(2) Pengembangan angkutan umum mencakup:

a. pengembangan secara bertahap sistem terpadu angkutan umum massal antar kota dan Kawasan Metropolitan Sarbagita yang ramah lingkungan dan menggunakan energi terbarukan;

b. pengembangan sistem trayek terpadu dan terintegrasi baik antar kota, kawasan perkotaan maupun kawasan perdesaan; dan

c. pengembangan kebijakan untuk menekan pemanfaatan terminal khusus pariwisata dalam bentuk sentral parkir di pusat-pusat kawasan pariwisata yang telah berkem- 
bang.

Dasar hukum pengelolaan pariwisata seperti yang telah diuraikan di atas menjadi pijakan bagi pelaksanaan pengelolaan daerah wisata, tata ruang dan transportasi yang menunjang suatu daerah wisata. Pemerintah sebagai salah satu stakeholder memiliki peran dalam pengembangan pariwisata. Peran pemerintah dalam mengembangkan pariwisata secara garis besarnya adalah menyediakan infrastruktur (tidak hanya dalam bentuk fisik), memperluas berbagai bentuk fasilitas, kegiatan koordinasi antara aparatur pemerintah dengan pihak swasta, pengaturan dan promosi umum ke daerah lain maupun ke luar negeri. Pemerintah mempunyai otoritas dalam pengaturan, penyediaan, dan peruntukan berbagai infrastruktur yang terkait dengan kebutuhan pariwisata. Tidak hanya itu, pemerintah bertanggung jawab dalam menentukan arah yang dituju perjalanan pariwisata. Kebijakan makro yang ditempuh pemerintah merupakan panduan bagi stakeholder yang lain di dalam memainkan peran masing-masing. Pemerintah sejauh mungkin dapat mengikutsertakan masyarakat setempat dan stakeholder lain dalam perencanaan dan pengembangan.

\section{Tinjauan Ekonomi Kemacetan dan Transportasi Publik di Kuta}

Sudah saatnya Bali memiliki sistem transportasi publik berkelas internasional, agar cocok dengan image Bali di dunia modern. Kalkulasi ekonomis pembangunan transportasi publik berkelas internasional memang memerlukan biaya yang sangat besar. Namun, kemanfaatannya yang sangat besar menjadikan pembangunan transportasi publik ini harus diperjuangkan. Gubernur Bali I Made Mangku Pastika dalam acara Lokakarya Pengembangan Transportasi Perkotaan, 20 November 2013, mengatakan pengembangan transportasi publik menjadi keniscayaan bagi sebuah kota metropolitan yang ke- banyakan tersandera masalah kemacetan. Pengembangan transportasi oleh pemda sering terhambat oleh kebutuhan investasi yang besar. Pemprov Bali membutuhkan dukungan dana sebesar Rp60,3 miliar pada tahun-tahun mendatang untuk pengembangan transportasi publik. Adapun pada 2015, kebutuhannya lebih kecil, yaitu Rp54,6 miliar. Perbandingan kebutuhan investasi di Surabaya untuk pengembangan transportasi publik mencapai Rp6,42 triliun pada 2014 sampai 2016. Pemkot Surabaya hanya mampu menyediakan pembiayaan sebesar Rp2,74 triliun.

Dari data yang dirilis oleh BKPM nilai realisasi investasi hingga triwulan III 2015, investasi di bidang infrastruktur mencapai Rp90,5 triliun, tumbuh 12,4\% dibandingkan tahun lalu. Dari investasi tersebut, subsektor transportasi, gudang, dan telekomunikasi mencapai Rp52,59 triliun dengan total 505 proyek. Kepala BKPM Franky Sibarani menyampaikan bahwa tidak hanya realisasi investasi yang meningkat, dari sisi komitmen investasi juga meningkat. Sektor infrastruktur mencatat nilai komitmen tertinggi, Rp 570 triliun atau setara dengan $43,84 \%$. Ini menunjukkan sektor infrastruktur, termasuk di dalamnya transportasi masih sangat menarik bagi investor. Upaya mengembangkan investasi di bidang transportasi, juga harus mampu menjawab tantangan di bidang transportasi, antara lain kemacetan dan ketersediaan transportasi publik yang memadai.

Provinsi Bali memiliki persoalan transportasi yang sangat berat dan kompleks. Untuk transportasi darat, bila dilihat dari skala makro, ada dua kondisi umum yang perlu mendapatkan perhatian. Pertama adalah yang terkait dengan kondisi lalu lintas (traffic) dan kedua adalah kondisi angkutan (transport). Saat ini pelayanan transportasi publik belum dapat memberikan jaminan pelayanan yang 
baik. Persentase pengguna transportasi publik sangat sedikit, bahkan kurang dari $3 \%$. Sebagian terbesar para pengguna jalan menggunakan transportasi pribadi, terutama sepeda motor yang kepemilikannya melampaui $70 \%$.

Pengenalan dan pengembangan transportasi publik massal melalui Bus Rapid Transit (BRT) yang diberi label Trans Sarbagita adalah salah satu bentuk upaya untuk mengatasi kemacetan lalu lintas melalui penyediaan palayanan transportasi publik yang lebih baik (Bisnis: 2015). Dampaknya adalah akan makin banyak/luas wilayah yang dapat dilayani oleh transportasi publik. Saat ini wilayah-wilayah yang tidak terlayani akan tetap menghasilkan pengguna transportasi pribadi dan akan selalu menjadi sumber kemacetan. Pemerintah harus segera menyediakan investasidalam transportasi publik sebelum melaksanakan pembatasan-pembatasan maupun upaya untuk menaikkan harga bahan bakar minyak. Jika pilihan untuk bertransportasi cukup banyak dan terjangkau maka secara otomatis akan terjadi pengurangan penggunaan kendaraan pribadi, karena mereka akan serta merta beralih ke transportasi publik termasuk di daerah wisata.

Wacana pembangunan jaringan kereta api mengelilingi Bali masih tetap bergulir. Kepala Dishub, Infokom Provinsi Bali Ir. Ketut Artika, MT, pada acara dialog publik "Menggagas Pembangunan Perkereta-apian Di Bali" menyampaikan publik harus mengerti tentang jenis-jenis layanan kereta api, teknologi kereta api dan aspek-aspek yang harus dipertimbangkan dalam pemilihan moda kereta api yang akan diterapkan di Bali. Sekretaris Direktorat Jenderal Perkereta-apian Kemenhub, Sugiadi Waluyo berpandangan studi kelayakan perkereta-apian tersebut lebih cocok disusun Pemprov Bali sendiri supaya tidak sampai terjadi gesekan dari sisi warna budaya, sedangkan kalau dibuat oleh swasta maupun perguruan tinggi, ten- tunya yang diutamakan hanya kelayakan dari sisi ekonomi dan teknisnya. Investasi transportasi sangat mahal termasuk pengoperasian kereta api memerlukan subsidi yang mahal. Namun efektifitas dan efisiensi sangat tinggi dalam penggunaan kereta api. Kereta api dapat menampung lebih banyak penumpang, lebih hemat bahan bakar yang artinya mengatasi kepadatan lalu lintas sekaligus menjaga lingkungan dari paparan polusi.

Pihak swasta atau investor asing dapat bekerjasama dengan pemerintah untuk mengusahakan percepatan pembangunan transportasi publik ini. Untuk itu pemerintah harus meningkatkan lagi gairah investasi dengan mengatasi kendala-kendala yang sering dipermasalahkan para investor seperti law enforcement yang buruk dan kematangan berpolitik di indonesia masih rendah. Kestabilan suhu politik dan ekonomi harus terus dijaga.

Agustina Murbaningsih, Asdep Bidang Prasarana, Riset, Teknologi, dan Sumber Daya Alam Setkab menyebutkan masterplan Percepatan dan Perluasan Pembangunan Ekonomi Indonesia (MP3EI) sampai dengan akhir 2013, terdapat 365 proyek strategis MP3EI yang tersebar di enam Koridor Ekonomi (KE) dengan nilai mencapai Rp. 828,7 triliun. Dari jumlah nilai tersebut swasta memberikan kontribusi pembiayaan sebesar Rp. 323,32 triliun. Sedangkan BUMN memberikan kontribusi sebesar Rp. 212,88 triliun, dan pemerintah sebesar Rp. 131,71 triliun. Direncanakan pada tahun 2014 akan dilakukan groundbreaking 166 proyek dengan nilai investasi Rp. 628,91 triliun. Sehingga total realisasi investasi MP3EI hingga akhir 2014 diperkirakan mencapai Rp. 1.457,63 triliun. Dari angka tersebut Rp. 627,39 triliun dialokasikan untuk meningkatkan konektivitas melalui pembangunan berbagai infrastruktur salah satunya penyelenggaraan perkeretaapian di Bali untuk mendukung pariwisata. 
Sambil menunggu pembangunan transportasi publik modern, pemerintah harusnya meng-edukasi masyarakat akan pentingnya transportasi publik. Sehingga transportasi publik menjadi pilihan utama selain kendaraan pribadi, sekaligus membudayakannya di tengah-tengah masyarakat. Jangan sampai setelah ada komitmen kerjasama antara pemerintah dengan swasta atau investor asing untuk pengadaan transportasi publik yang baik dan berskala internasional namun masyarakat masih enggan, atau gengsi untuk memakai transportasi publik. Transportasi publik yang telah ada dimaksimalkan pelayanan, kenyamanan, harga, aksesabilitas dan keamanannya sehingga orang tertarik menggunakannya sehingga membawa kemaslahatan bagi masyarakat, percepatan pembangunan dan pertumbuhan iklim investasi.

Belajar dari daerah lain di Indonesia maupun kota-kota besar dunia dalam hal menangani masalah transportasinya, tentu saja diadaptasi dengan kondisi sosial budaya masyarakat Bali sehingga dapat menentukan alternatif terbaik untuk pengadaan transportasi publik khususnya di daerah rawan kemacetan seperti di daerah wisata Kuta. Diperlukan kreatifitas untuk menarik minat swasta dan investor asing. Alternatif terbaik dalam mengatasi kemacetan tersebut dapat menjadi sebuah kebijakan baru yang berhasil jika implementasinya didukung oleh semua elemen stakeholders mulai dari pemerintah sebagai pengambil kebijakan, pelaku usaha pariwisata, wisatawan, masyarakat lokal dan investor tentu saja dengan tetap mempertahankan budaya dan kearifan lokal Bali.
DAFTAR PUSTAKA

\section{A. Buku/ Jurnal}

Indiahono, Dwiyanto. 2009. Kebijakan Publik Berbasis Dynamic Policy Analysis. Gava Media. Yogyakarta.

Muhammad, Fadel. E-book: Reinventing Local Government untuk Memberdayakan Birokrasi Pemerintah Daerah. 2006. Mempraktekkan Entrepreneurial Government. Pustaka Indonesia Press. Jakarta

Widodo, Joko. 2013. Analisis Kebijakan Publik: Konsep dan Aplikasi Analisis Proses Kebijakan Publik. Bayumedia Publishing. Malang.

\section{B. Internet}

http://dishubinkom.baliprov.go.id/id/ANGKUTAN-UMUM-Trans-SARBAGITA

ht tp: // re posi tory.usu.a c.id/bi tstream/123456789/17995/1/adkmei2006-3\%20(1).pdf

h t t p : / / s u a r a d e w a t a . c o m / $\mathrm{read} / 2016 / 04 / 01 / 201604010011 / \mathrm{Di}$ Bali-Kendaraan-Bermotor-Capai-5Juta-Unit.html

\section{Peraturan Perundang-undangan}

Undang-Undang Nomor 22 Tahun 2009 tentang Lalu Lintas dan Angkutan Jalan

Peraturan Menteri Dalam Negeri Nomor 6 Tahun 2007 tentang Petunjuk Teknis Penyusunan dan Penetapan Standar Pelayanan Minimal

Peraturan Pemerintah Nomor 65 Tahun 2005 tentang Pedoman Penyusunan dan Penerapan Standar Pelayanan Minimal

Undang-undang Nomor 10 Tahun 2009 tentang Kepariwisataan

Peraturan Daerah Provinsi Daerah Tingkat I Bali Nomor 16 Tahun 2009 tentang Rencana Tata Ruang Wilayah Provinsi Bali Tahun 2009-2029 